\title{
Suppletive kin term paradigms in the languages of New Guinea
}

Matthew Baerman, Surrey Morphology Group, University of Surrey

[to appear in Linguistic Typology 18.3 (2014)]

\section{Abstract}

Kin terms in some languages have suppletive roots according to the person of the possessor, as in Kaluli na:la 'my daughter', ga:la 'your daughter' versus ida 'her/his daughter'. Suppletion is generally seen as a language-specific morphological peculiarity, but in this context there are a number of lexical and morphological similarities across languages, suggesting the motivation may also lie in the nature of kin terms themselves. We offer a typological assessment suppletive kin terms through a case study of the languages of New Guinea, where the phenomenon appears to be particularly common.

Keywords: morphology, suppletion, kin terms, New Guinea, possession

\section{Introduction}

Kin terms in some languages may have suppletive roots according to the person of the possessor. Consider the words for 'mother' and 'mother-in-law' in (1) from Ankave (TransNew Guinea phylum, Angan family). Both words mark possessor person with prefixes $\left(2^{\text {nd }}\right.$ person $r \dot{t}-, 3^{\text {rd }}$ person $x \dot{t}$-, and zero for $1^{\text {st }}$ person), while 'mother' additionally displays a distinction between a $1^{\text {st }}$ person root ino' $k i$ and a $2^{\text {nd }} / 3^{\text {rd }}$ person root $n a ' i$. 


\begin{tabular}{|c|c|c|}
\hline & 'mother' & 'mother-in-law' \\
\hline 1 & ino'ki' & neagwi' \\
\hline 2 & ri-na'i' & ri-neagwi' \\
\hline 3 & xi-na'i' & xi-neagwi' \\
\hline
\end{tabular}

While suppletion for number is a familiar occurrence in nominal paradigms (e.g. one person $\sim$ two people), suppletion for properties of the possessor largely remains unexplored territory, though it has periodically been noted in the typological literature (e.g. Croft 1990, Dahl \& Koptjevskaja-Tamm 2001, Drossard 2004, Heath 2004, Mel’čuk 2006, Dziebel 2007, Vafaiean 2013, Aikhenvald 2013). Its particular interest comes from the way it combines properties of inflectional paradigms on the one hand with the pragmatically motivated distribution of distinct lexical items on the other. As Heath (1982: 13f) writes, suppletive alternations

...might have something to do with elusive aspects of speech pragmatics or with emotive accretions on words which are inappropriate to some forms. [...] Because we are dealing with highly grammaticalised alternations there is no simple test to determine what attitudes the various stems evoke in speakers, but we cannot assume that just because the stem alternations are categorical (automatically determined by pronominal affixes) there is nothing further to be said about them than just to list them. (pp 13f)

Dahl \& Koptjevskaja-Tamm (2001) provide a useful bridge between pragmatics and morphology with their discussion of what they call KIN TERM DOUBLETS, such as mommy vs. 
mother), whose relative frequency may well differ according to the person of the possessor. They write:

The members of kin term doublets usually differ with respect to their use. A common pattern is for one member to be more frequent in vocative and egocentric uses.

Sometimes, this seems to be regularized to an extent where it is motivated to talk of suppletion within a single paradigm. (p. 217)

On this view we expect a split between $1^{\text {st }}$ person possessors and the rest, which is indeed what we find in (1). But this is far from being the whole story. For example, in the word for 'father' in Ekagi (Trans-New Guinea phylum, Wissel Lakes family) there is a split between the $3^{\text {rd }}$ person root $n a$ and the root ajtaj found elsewhere, while in Vitu (Western Oceanic) there is a split between $2 \mathrm{SG}$ mama and the root tama found elsewhere (the inflectional affixes are also different; see $\$ 4.3$ below).

(2) Ekagi (Drabbe 1952: 16f)

suppletive non-suppletive

'father' 'uncle'

\begin{tabular}{|l|l|l|}
\hline 1SG & na-ajtaj & na-ama \\
\hline 2SG & aka-ajtaj & aka-ama \\
\hline 3SG & na-kamee & ama-kamee \\
\hline
\end{tabular}




\begin{tabular}{|l|l|l|}
\multicolumn{1}{c}{} & \multicolumn{1}{c}{ suppletive } & \multicolumn{1}{c|}{ non-suppletive } \\
'father' & 'spouse' \\
\hline 1SG & tama-gu & go-gu \\
\hline 2SG & ka-mama & go-o \\
\hline 3SG & tama-na & go-na \\
\hline
\end{tabular}

Evidently, there is a range of varying patterns, and not just a simple opposition between ego and other. But what these are and how to account for them has not yet been explored; there is no comprehensive overview, the existing work citing only isolated examples. There are good reasons for this. Such suppletive patterns do not appear to be frequent, either in terms of the number of languages they occur in, or the number of lexical items affected (never more than a handful in a given language). For example, Vafaeian (2013) in a cross-linguistic survey of suppletion in nouns in 64 languages (incorporating the sample used by Brown et al. 2004), includes only three languages with possessor-person based suppletion. ${ }^{1}$ In practical terms, suppletive paradigms are hard to spot, since the authors of language descriptions may not flag them overtly, or omit mention of them completely. But the available evidence indicates that they are nevertheless found in a range of unrelated languages across the world, sharing a number of properties, which makes them a potentially fruitful topic of typological enquiry.

Given the rather elusive nature of the phenomenon, and the fact that the relevant typological parameters have not yet been defined, a definitive cross-linguistic investigation will be a daunting undertaking. As a first step we have undertaken the pilot study presented

\footnotetext{
${ }^{1}$ Quite a few more languages in the sample show suppletion according to whether or not the noun is possessed at all, but without values of person playing a role.
} 
here, which is restricted to the languages of New Guinea. This region offers three advantages: (i) morphological marking of the possessor on kin terms is common, (ii) a variety of different patterns are found, and (iii) there is a large number of distinct language families. Our method has simply been to consult all the descriptions we have had access to, which runs into the hundreds. From that sample, the languages which are demonstrably of relevance are listed in Table 1, and their locations are indicated on Map 1.

The paper is structured as follows. $§ 2$ outlines the morphological characteristics of possessor person marking: its degree of irregularity, and its relationship to other categories that the language distinguishes morphologically. $\S 3$ explores the lexical items involved, and how these relate to pragmatically determined differences in the use of kin term doublets. $\S 4$ surveys the different paradigmatic patterns in terms of how different person values are opposed to each other, and how they interact with number. $\S 5$ asks to what extent these paradigms can still be treated as lexical competition, and to what extent they are better seen as morphologically encoded paradigms. $§ 6$ concludes, and opens up the prospect of crosslinguistic study of much wider scope. 


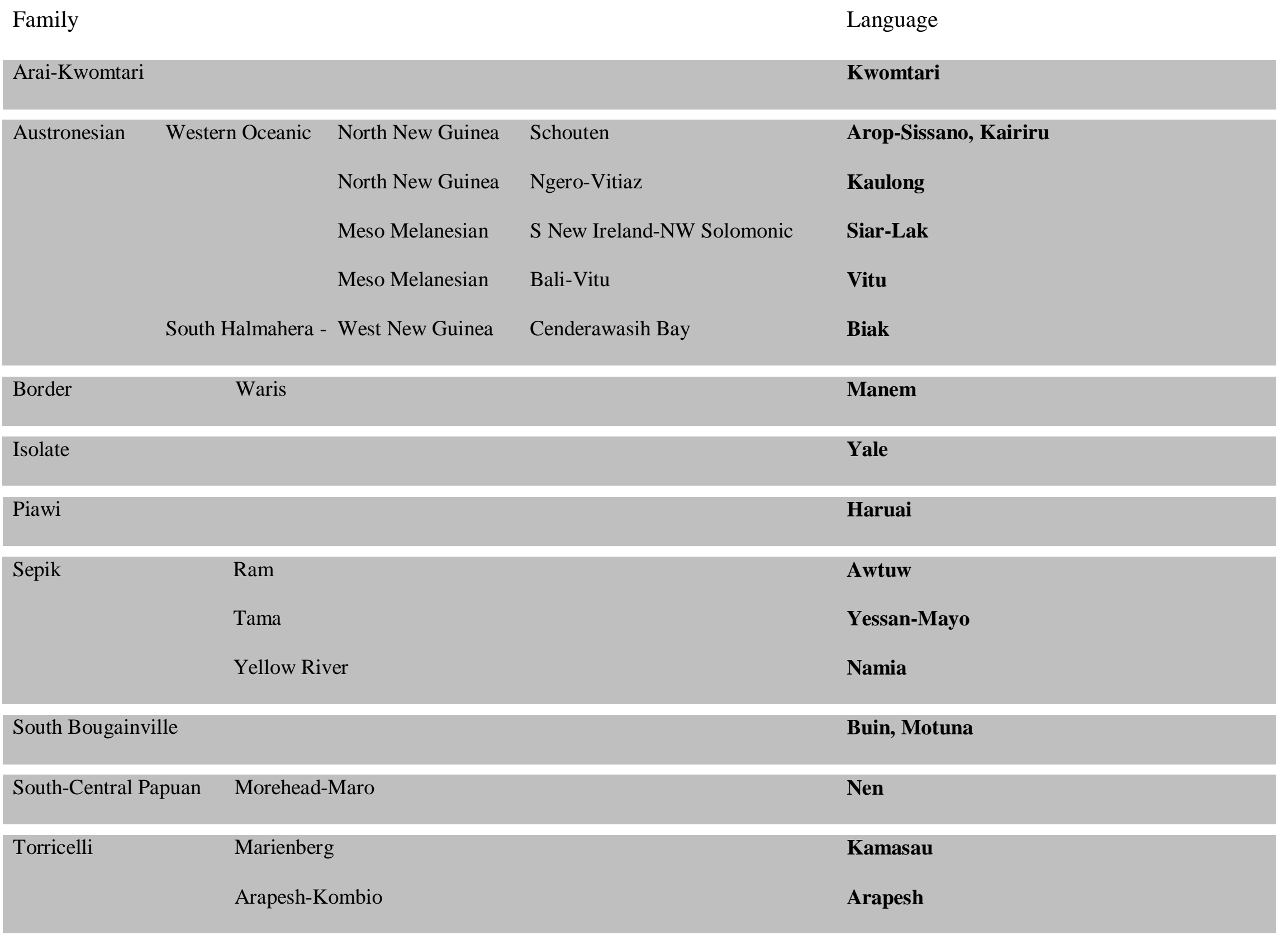




\begin{tabular}{|c|c|c|c|c|c|}
\hline \multirow[t]{10}{*}{ Trans-New Guinea } & \multicolumn{4}{|l|}{ Binanderean } & \multirow{2}{*}{$\begin{array}{l}\text { Korafe } \\
\text { Golin, Salt-Yui }\end{array}$} \\
\hline & \multirow[t]{2}{*}{ Chimbu-Wahgi } & \multicolumn{3}{|l|}{ Chimbu } & \\
\hline & & \multicolumn{3}{|l|}{ Hagen } & Imbongu, Umbu-Ungu \\
\hline & \multicolumn{4}{|l|}{ Kainantu-Goroka } & Waffa \\
\hline & Madang & Croisilles & Pihom & Kumilan & Mauwake \\
\hline & & Croisilles & Pihom & Numugenan & Usan \\
\hline & & \multicolumn{3}{|l|}{ Kalam-Kobon } & Kalam, Kobon \\
\hline & & \multicolumn{3}{|l|}{ Rai Coast } & Tauya \\
\hline & Ok-Oksapmin & \multicolumn{3}{|l|}{ Mountain Ok } & Bimin, Telefol, Tifal \\
\hline & & \multicolumn{3}{|l|}{ Oksapmin } & Oksapmin \\
\hline & West, Wissel Lakes & & & & Ekagi \\
\hline \multirow[t]{3}{*}{ Trans-New Guinea? } & \multicolumn{4}{|l|}{ Angan* } & Akoye, Ankave, Kapau, Menya, Tainae \\
\hline & \multicolumn{4}{|l|}{ Bosavi* } & Kaluli \\
\hline & \multicolumn{4}{|l|}{ Yareban* } & Yareba \\
\hline
\end{tabular}

Table 1: Languages described in this study, classification based on Ethnologue, with Loughnane and Fedden (2011) for Ok-Oksapmin.

Families marked with '*' are not treated as Trans-New Guinea by Glottolog. 
[Map 1 about here]

Map 1: New Guinea and surroundings, showing locations of the languages or language families listed in Table 1

\section{The morphological context}

To paraphrase Mel'čuk's succinct formulation, suppletion involves a maximally regular semantic relationship and a maximally irregular formal relationship (Mel'čuk 1994:358, cited by Corbett 2007:11). In the most obvious case we have etymologically unrelated roots participating in a single inflectional paradigm, as with go and went. But there is no general agreement on how unrelated two forms have to be to warrant the name; indeed, there are schools of analysis that treat any formal alternation not ascribed to concatenation plus subsequent phonological rules as suppletion. For heuristic purposes we have aimed here for a fairly restrictive understanding of suppletion, limiting our scope to gross differences in the lexical root. That said, in some of the languages we see a cline of irregularity, with suppletive roots occurring in cells of the paradigm which are otherwise the target of lower-level irregularity, so that that there is a unified domain of morphological irregularity that includes, but is not restricted to, suppletion (see Corbett 2007:22). For example, in Motuna (see (4)), morphological irregularity is concentrated in the 1SG. The regular system found with kin terms is illustrated by nura 'my daughter-in-law'. Nuka 'my mother' has an irregular stemfinal vowel alternation. Poowoi 'my brother-in-law' has an irregular prefix, identical to the 3SG. Umoka 'my father' appears to have a suffix rather than a prefix. Maama lacks a prefix, and while the general shape of the root carries across the whole paradigm $(m V m V)$, the vowels alternate in quality and length. Taataa 'my older brother' is fully suppletive. 
(4) Motuna (Onishi 1994:94-107)



note: prefix vowel/o/ assimilates to the vowel of the following syllable; 1SG /i/ fuses with and raises an immediately following vowel

More broadly, the morphological marking of possessor person on nouns as such is exceptional, at least in the languages of the sample, as discussed in the following section; in nearly all cases it is restricted to kin terms. The links that this system has with the rest of the morphology varies widely across the languages. At one end there are languages where possessor marking is transparently derived from pronominal morphology. Motuna is one of these; compare the free pronouns $n i$ 'I' and ro 'you' (singular) with the prefixes in (4). At the other end, the morphology appears to involve some word-formation process not directly related to person marking. For example, in Awtuw (5), specifically male and female variants of napre 'opposite sex sibling' are derived through suffixation, but only for non- $1^{\text {st }}$ person possessors. And in Tauya (6), distinct 3SG possessive forms of kin terms are derived through the polyfunctional suffixes $-f o$ or $-m o$, which are found on various nominals in the language, in particular adjectives (amufo 'large', ?ufumo 'heavy'). 
(5) Awtuw 'opposite sex sibling' (Feldman 1986:173)

$$
\begin{array}{ll}
\text { 'brother 'sister } & \\
\text { (to sister)' (to brother)' }
\end{array}
$$

\begin{tabular}{|l|l|l|}
\hline 1 & \multicolumn{2}{|l|}{ napre } \\
\hline 2 & napre-r & napre-t \\
\hline 3 & & \\
\hline
\end{tabular}

(6) Tauya (MacDonald 1990:88, 97)

$\begin{array}{lll} & \text { general form } & \text { 3SG form } \\ \text { 'son' } & \text { Pita } & \text { Pita-fo } \\ \text { 'husband' } & \text { ota } & \text { ota-fo }\end{array}$

In Mountain Arapesh there is comparative evidence that the morphology of possessed nouns has a somewhat loose relationship to person marking. In the dialect spoken in the village of Wautigok, the distinction between $1^{\text {st }}$ person and non- $1^{\text {st }}$ person forms involves a variety of morphological operations (in general, the non- $1^{\text {st }}$ person form appears to be the morphologically derived one; Dobrin 1997:109). In the neighbouring village of Balam kin terms have only a single form, which generally corresponds to the (derived) non- $1^{\text {st }}$ person form of Wautigok. In the village of Dogur, to the other side of Wautigok, the formal contrast is also reduced, at least for some items, but in this case in the direction of the $1^{\text {st }}$ person form. This suggests that the marking of person as such is not inherent to these forms. 
(7) Comparison of Mountain Arapesh varieties (Dobrin 1997:108)

\begin{tabular}{|c|c|c|c|c|c|c|}
\hline \multicolumn{3}{|c|}{ Wautigok } & \multicolumn{2}{|l|}{ Balam } & \multicolumn{2}{|l|}{ Dogur } \\
\hline & \multicolumn{2}{|l|}{ 'maternal } & \multicolumn{2}{|c|}{ 'maternal } & \multicolumn{2}{|c|}{ 'maternal } \\
\hline & uncle' & 'mother' & uncle' & 'mother' & uncle' & 'mother' \\
\hline 1 & wawen & yamo & & & & \\
\hline 2 & & & wawen & yam & waken & amakek \\
\hline 3 & & & & & & \\
\hline
\end{tabular}

Finally, there are cases where the morphology of possessed kin terms is so irregular that it is difficult or impossible to identify any regular system, let alone characterize it as pronominal or not. For example, in Kwomtari, the kin terms in (8) look as if they can be analysed as non-suppletive lexemes with segmentable prefixes according to three different patterns. But out of the eleven possessor-marked kin terms given by Spencer (2008:58), only these three behave this way (the rest are suppletive and even less obviously segmentable), so segmentation is a dubious undertaking to begin with. And in any case, the resulting prefixes have no obvious parallels in the pronominal system or anywhere else in the language.

(8) Kwomtari (Spencer 2008:58)

'younger sibling

'ancestor' same sex' 'male's sister'

\begin{tabular}{|l|l|l|l|}
\hline 1 & \multirow{2}{*}{ ambue } & wo-moo & wo-foli \\
\hline 2 & & & \\
\hline 3 & n-ambue & moo & ya-foli \\
\hline
\end{tabular}


The overall impression one gets is that the occurrence of suppletion is independent of the morphological and morphosyntactic particulars of possessor marking in the languages in question. That is, it occurs both in languages where possessor marking is transparently pronominal and thus explicitly encodes person (e.g. Motuna), and in those where the relationship to person values is oblique at best (e.g. Awtuw, where it is only gender which is explicitly marked). Indeed, as will be shown below, the patterns of suppletion show far more similarity cross-linguistically than do the systems of 'regular' affixal marking, suggesting that suppletion here is not simply a morphological irregularity, but has some other motivation shared across these languages, due perhaps to functional or semantic factors.

\section{The lexical context}

Possessor person based suppletion in the sample is almost entirely limited to kin terms. This is a striking restriction, but one whose significance is tempered by the fact that the morphological marking of possessor person itself is found only with kin terms in all but the Oceanic languages, and the Trans-New Guinea languages Golin and Tauya. (Tauya does show suppletion in body part terms as well, a point which we return to in §7.) But within this constrained domain we can make a number of lexical generalizations.

In Dahl \& Koptjevskaja-Tamm's discussion, suppletive kin terms are portrayed as an extreme example of the functionally segregated distribution of two distinct but referentially equivalent terms. On that interpretation, the paradigms we are considering here represent, either synchronically or diachronically, the collaboration of two or more lexical items. Although we do not know if this is always the case, it does provide a useful point of departure. Dahl \& Koptjevskaja-Tamm suggest that these mixed paradigms are the product of lexical replacement, with novel kin terms entering the paradigm in vocative and egocentric 
use, and that there is a link between which kin terms are affected and what replacement forms are used:

- Following what they call the parental prototype, terms for ascending generations prototypically parents - will be renewed with "nursery language" (e.g. reduplicated forms like mama and papa), loanwords, slang or diminutives.

- Terms for horizontal generations (e.g. spouses) and descending generations (e.g. children) will be renewed with improper kin terms. Improper kin terms are those where 'there is also a non-kin (typically non-relational) use which is at least as salient as the kin use' (Dahl \& Koptjevskaja-Tamm 201: 202), e.g. woman, girl, boy, as opposed to wife, daughter, son.

Reflections of these patterns are found throughout the current sample. Consider first the parental prototype. Thus, in Kamasau (9), the term for 'older sibling' has a suppletive paradigm but the term for younger sibling does not. The $1^{\text {st }}$ person form is of the reduplicated sort, and so has the characteristics of "nursery language".

(9) Kamasau (Sanders \& Sanders 1994:12)

suppletive non-suppletive

'older sibling' 'younger sibling'

\begin{tabular}{|l|l|l|}
\hline 1 & jeje & qam \\
\hline 2 & nu-se & nu-qam \\
\hline 3 & ki-se & ki-qam \\
\hline
\end{tabular}


A particularly telling example comes from Siar-Lak (10), where there is a reciprocal term that means either 'grandparent' or 'grandchild'. A grandparent speaking about their grandchild uses the regularly inflected non-suppletive form, while a grandchild speaking about their grandparent uses a reduplicated suppletive form (which distinguishes sex, unlike the regular term).

(10) Siar-Lak (Rowe 2005:42-44)

'grandchild' 'grandfather' 'grandmother'

\begin{tabular}{|l|l|l|l|}
\hline $1 \mathrm{SG}$ & tubu-k & tété & wowo \\
\hline $2 \mathrm{SG}$ & \multicolumn{2}{|c|}{ tubu-m } \\
\hline $3 \mathrm{SG}$ & \multicolumn{2}{|c|}{ tubu-n } \\
& & \\
\hline
\end{tabular}

The use of improper kin terms is illustrated in (11) for languages with a dominant pattern of $1^{\text {st }} \sim$ non- $1^{\text {st }}$ suppletion. In Kobon, the $1^{\text {st }}$ person form for 'husband' is the generic word 'man' (Davies 1981:234), while in Tainae, the $1^{\text {st }}$ person form of 'wife' is the generic word for 'woman' (Carlson 1991:42). In Yale, the $1^{\text {st }}$ person form for 'child' is the generic word that appears also in non-referential contexts in various examples in Campbell \& Campbell's (1987) grammar (in which case the non- $1^{\text {st }}$ person root $-k o$ might better be glossed as something like 'offspring'). 
(11) Paradigms employing improper kin terms for $1^{\text {st }}$ person possessors

\begin{tabular}{|l|l|l|l|}
\multicolumn{2}{c}{ Kobon } & \multicolumn{1}{l}{ Tainae } & \multicolumn{1}{l}{ Yale } \\
\multicolumn{2}{c}{ 'husband' 'wife' } & 'child' \\
\hline 1 & bi & apaki & nëba \\
\hline 2 & na-gmul & sa-pepi & bi-ko \\
\hline 3 & nu-gmul & ki-apepi ${ }^{2}$ & bo-ko \\
\hline
\end{tabular}

Useful as this triage of kin types may be (ascending, horizontal, descending generations), one should bear in mind that this provides only a rough guide. Consider the data from Kamasau more closely. Sanders \& Sanders (1994) list the seventeen kin terms shown in (12). Seven are clearly suppletive, and two ('mother' and 'father') are irregular in that they appear to have otherwise unattested affixes, which are underlined here. Nearly all these refer to older relatives, but then 'cross cousin' is an exception. Otherwise, terms denoting horizontal or descending relations are all non-suppletive, but so are various terms denoting older relative (the final four in the list). As a further detail note the gloss for mem, which shows that individual kin terms may extend to various denotationally distinct relationships, describing in some cases fairly complex networks; this additional complication will however not affect the rough triage we have made.

(12) Kamasau kin terms (Sanders \& Sanders 1994:12)

$\begin{array}{llcc} & 1 & 2 & 3 \\ \text { 'mother' } & \text { mo-yu } & \text { nu-mo } & \text { ku-mo } \\ \text { 'older sibling' } & \text { jeje } & \text { nu-se } & \text { ki-se } \\ \text { 'maternal grandparent' } & \text { koku } & \text { nu-qo } & \text { ku-qo }\end{array}$

\footnotetext{
${ }^{2}$ Carlson (1991) gives this form with the plural suffix - $p a$ in place of singular - $p i$; we interpret this as a typo.
} 


\begin{tabular}{|c|c|c|c|}
\hline 'cross cousin' & yai & nu-qangri & ki-qangri \\
\hline 'mother's younger sister' & mom & nu-motumo & ku-motumo \\
\hline 'father's sister' & bobo & nu-nyam & ki-nyam \\
\hline 'father's younger brother' & mom & nu-yitumo & ki-yitumo \\
\hline 'father' & $\underline{\text { wu}}-\mathrm{yi}$ & nu-yi & ki-yi \\
\hline 'son' & wonyimi & nu-wonyimi & ku-wonyimi \\
\hline 'daughter' & wonyumbu & nu-wonyumbu & ku-wonyumbu \\
\hline 'younger sibling' & qam & nu-qam & ki-qam \\
\hline 'brother' & nyimi & nu-nyimi & ki-nyimi \\
\hline 'sister’ & nyumbu & nu-nyumbu & ki-nyumbu \\
\hline 'in-law (spouse's parent)' & yine & n-ine & $\mathrm{k}$-ine \\
\hline \multicolumn{4}{|l|}{ 'paternal grandparent/ } \\
\hline father's older brother' & mem & nu-mem & ki-mem \\
\hline 'mother's older sister' & bar & nu-bar & ki-bar \\
\hline 'mother's brother' & wau & nu-wau & ku-wau \\
\hline
\end{tabular}

As noted above, Dahl \& Koptjevskaja-Tamm suggest that the suppletive egocentric forms may have a diachronic interpretation, in that $1^{\text {st }}$ person possessors are the locus for innovation. If this is the case, we should expect to see greater variation in the egocentric forms when comparing related languages. The only families in the sample for which this can reasonably be done are Angan and Mountain Ok. For the Angan languages, we can compare several words across the five languages Akoye, Tainae, Kapau, Menya and Ankave. Some appear to be cognate in all their forms: 'maternal uncle' (not suppletive), 'wife' (suppletive, with the improper kin term 'woman' for $1^{\text {st }}$ person) and 'father'. But the words 'grandfather' and 'grandmother', though clearly cognate in their non- $1^{\text {st }}$ person forms, show some variation 
in the $1^{\text {st }}$ person forms (13). Akoye has distinct t-initial forms for both 'grandfather' and 'grandmother', while Menya 'grandfather' lacks suppletion, so that its $1^{\text {st }}$ person form does not match the others.

(13) Comparison of various Angan cognates (Whitney \& Whitney 1991:57, Carlson 1991:42, Speece 2006, Oates \& Oates 1968:164, Whitehead 2004:231)

\begin{tabular}{|c|c|c|c|c|c|c|}
\hline & & Akoye & Tainae & Kapau & Ankave & Menya \\
\hline \multirow[t]{3}{*}{ 'grandmother' } & $1 \mathrm{SG}$ & täitä & atae-pi & äti & asi' & asi-pa \\
\hline & $2 \mathrm{SG}$ & s-ää & sa-yae-pi & t-äi & r-i'a'i' & t-ai \\
\hline & $3 \mathrm{SG}$ & ka-yää & k-iae-pi & q-äi & xi-i'a'i' & k-ai \\
\hline
\end{tabular}

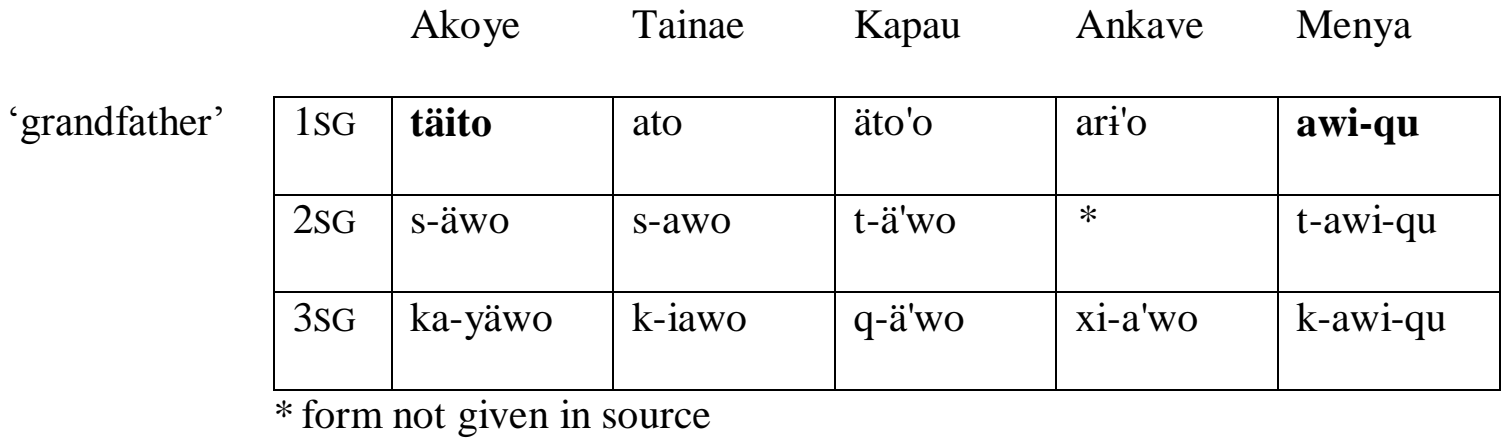

In the Mountain Ok languages, the $1^{\text {st }}$ person form for 'mother' differs between the three languages that we have data for, while the non $-1^{\text {st }}$ person form is cognate. Alongside this we have the evidence of Mian, a Mountain Ok language which lacks morphological possessor marking. The default term for 'mother' is awók, cognate with the non- $1^{\text {st }}$ person form of the other languages, but there is also a doublet term biém, glossed as 'mum' (Fedden 2011:94), which suggests a pragmatic distinction that has not achieved paradigmatic status. 
(14) 'Mother' in three Mountain Ok languages (Healey 1962:15, Boush 1975:4, Weber 1997:20)

\begin{tabular}{|c|c|c|c|}
\hline & Telefol & Tifal & Bimin \\
\hline $1 \mathrm{SG}$ & $\begin{array}{l}\text { áb-eén, } \\
\text { áníb-eén }\end{array}$ & akum-een & yem \\
\hline $2 \mathrm{SG}$ & k-oók-eén & k-awok & k-ouk \\
\hline $3 \mathrm{SG}$ & oók-eén & awok & auk \\
\hline
\end{tabular}

In sum, the lexical properties of suppletive kin terms are remarkably similar across the languages of the sample, with respect both to the terms affected, and to the properties of the consituent roots, in particular the one used for $1^{\text {st }}$ person (or more broadly, egocentric) possessors. This suggests that the meaning of the kin term is itself an important determinant of the suppletive pattern, and that the choice of suppletive root is at least in part determined by shared lexical semantic strategies.

\section{Patterns of suppletion}

In line with prior discussions, we have so far framed the suppletive in terms of egocentric and non-egocentric usage. This implies the opposition $1^{\text {st }}$ person $\sim$ non- $1^{\text {st }}$ person, but as already indicated in $\S 1$, this is just one of various patterns found. Thus, given a distinction of three person values, all possible patterns are found (\$4.1-4.4), along with additional patterns as a result of interactions with number $(\$ 4.5)$. One of the goals of the survey below is to explore to what extent these other patterns can be derived from the notion of egocentric reference. 


\subsubsection{First person $\sim$ non-first person}

This pattern follows Dahl \& Koptjevskaja-Tamm's observation that suppletive kin term paradigms typically involve the opposition of egocentric reference versus other. And indeed, it is by far the most widely attested in the sample: all the languages in Table 1 display this pattern, except for those explicitly mentioned below in $\$ 4.2$ and $\$ 4.3$. Morphologically, the examples display a certain sameness, in that in every instance the $1^{\text {st }}$ person form appears to be a bare stem, without any discernable inflection. This parallels the use seen in many languages of bare kin terms (e.g. unmodified or indefinite) for egocentric reference, as in English, where mom or $d a d$ used on their own imply a $1^{\text {st }}$ person possessor (see Koch 1995: 51-55, Dahl \& Koptjevskaja-Tamm 2001: 205).

In some cases this bare stem replaces (or at least appears to replace) a regularly inflected form. For example, in Mauwake (15), non-suppletive lexemes typically take a $y$ prefix in the $1^{\text {st }}$ person, which is lacking with suppletive lexemes. The suppletive $1^{\text {st }}$ person form thus has a different morphological composition from the corresponding non-suppletive form. In others, such as Namia (16), the $1^{\text {st }}$ person form is normally the bare stem in any case.

Mauwake (Berghäll 2010:57)

\begin{tabular}{|l|l|l|}
\multicolumn{1}{c}{} & \multicolumn{1}{l}{ suppletive } & \multicolumn{1}{c}{ non-suppletive } \\
\multicolumn{1}{l}{ 'elder sibling' 'sister' } \\
\hline 1 & paapa & y-ekera \\
\hline 2 & n-eepe & n-ekera \\
\hline 3 & w-eepe & w-ekera \\
\hline
\end{tabular}




\begin{tabular}{|l|l|l|}
\multicolumn{1}{l}{$\begin{array}{l}\text { suppletive } \\
\text { 'grandfather' }\end{array}$} & non-suppletive \\
\multicolumn{2}{l}{} & 'older brother' \\
\hline 1 & aujwa & awa \\
\hline 2 & aipau-kwa & awa-kwa \\
\hline 3 & aipau-lwa & awa-lwa \\
\hline
\end{tabular}

In some cases the suppletive $1^{\text {st }}$ person form introduces a morphological distinction not otherwise present in the paradigm. In all the examples this occurs where the default paradigm makes a two-way distinction between $2^{\text {nd }}$ person and non- $2^{\text {nd }}$. Thus in Telefol, most kin terms have an overtly inflected $2^{\text {nd }}$ person form and a bare stem for $1^{\text {st }}$ and $3^{\text {rd }}$ person. The suppletive $1^{\text {st }}$ person form in 'mother's brother' introduces a third form. Compare this with the cognate item in closely related Tifal, which is not suppletive (17). Oksapmin shows essentially the same pattern: $1^{\text {st }}$ and $3^{\text {rd }}$ person typically take a suffix $-p$, and $2^{\text {nd }}$ person takes $-n$ (three lexemes take $-a$ ). Suppletive items have a distinct and apparently uninflected $1^{\text {st }}$ person root. Here there is telling evidence from dialect variation: in the Upper Oksapmin variety described by Lawrence (2006), the suppletion found in the Lower Oksapmin variety described by Loughnane is largely absent, so the intrusive nature of the suppletive $1^{\text {st }}$ person form is once again apparent.

(17) Variation between Telefol (Healey 1962:15) and Tifal (Weber 1997:20)

$\begin{array}{lll}\text { Telefol } & & \text { Tifal } \\ \text { 'father's } & \text { 'mother's } & \text { 'mother's } \\ \text { older brother' } & \text { brother' } & \text { brother' }\end{array}$




\begin{tabular}{|l|l|l|}
\hline 1 SG & aaloob & moom \\
\hline $2 \mathrm{SG}$ & k-aalob & k-okoot \\
\hline $3 \mathrm{SG}$ & aaloob & okoot \\
\hline
\end{tabular}

\begin{tabular}{|l|}
\hline (w)okos \\
\hline k-okos \\
\hline (w)okos \\
\hline
\end{tabular}

(18) Dialect variation in Oksapmin 'uncle' (Loughnane 2009:133, Lawrence 2006)

Lower Oksapmin $\quad$ Upper Oksapmin

\begin{tabular}{|l|l|l|}
\hline 1 & mam & əmnə-p \\
\hline 2 & əmnə-n & əmnə-n \\
\hline 3 & əmnə-p & əmnə-p \\
\hline
\end{tabular}

The Ok languages and Oksapmin are related, albeit somewhat distantly, but the same pattern is also found in Imbongu/Umbu Ungu (19), which is as good as unrelated (the languages belong to the Trans New Guinea Phylum, but have no closer relationship than that). Nonsuppletive items (of which Stefaniw 1987 only lists two) have two forms, one ending in -ena $\left(2^{\text {nd }}\right.$ person) and one in - enu $\left(1^{\text {st }} / 3^{\text {rd }}\right.$ person). Some of the suppletive lexemes look as if they start on the basis of this type of paradigm, with an intrusive $1^{\text {st }}$ person form.

(19) Imbongu (Stefaniw 1987:16)

suppletive non-suppletive

'son' 'daughter'

\begin{tabular}{|l|l|l|}
\hline $1 \mathrm{SG}$ & malo & lemenu \\
\hline $2 \mathrm{SG}$ & marena & lemena \\
\hline $3 \mathrm{SG}$ & marenu & lemenu \\
\hline
\end{tabular}




\subsection{Non-third person $\sim$ third person}

Suppletion that opposes a non- $3^{\text {rd }}$ person root to a $3^{\text {rd }}$ person root might be thought of as representing an opposition based on speech act participants, as suggested by Heath (2004:1003). It is certainly possible to find a plausible bases for this split in the pragmatics of kin term use. For example, Dahl \& Koptjevskaja-Tamm (2001: 202) invoke the distinction between in-family and out-of-family uses of kin terms, so that a term like Granny might be used equally with $1^{\text {st }}$ or $2^{\text {nd }}$ person reference when addressing family members, but would not as readily be used to refer to some else's grandmother from outside the family. But in a number of cases there is a further wrinkle: the suppletive non- $3^{\text {rd }}$ person form has properties that we have identified above as belonging specifically to $1^{\text {st }}$ person forms. Aikhenvald (2013:10f) suggests that that this comes from an extension of the notion of ego: ${ }^{3}$

'[i]n a number of languages, if the Possessor is the speaker or a Speech Act Participant, the possessive construction is more 'closely knit'. [...] What belongs to 'you' and 'me' as the Speech Act Participants can be envisaged as more close and more intimate, bearing a closer relationship to what Bally (1995 [1926]:33) referred to as the 'personal domain'. Conceptual proximity goes together with proximity in surface realization. This 'egocentric' aspect of possessive marking provides further evidence for the special status of speech act participants.

While we would not go so far as to say that semantic and morphological patterning necessarily go hand in hand, this suggestion provides a useful point of reference for this set of

\footnotetext{
${ }^{3}$ Though she discusses suppletion, the example she adduces to illustrate this (from the Mba language 'Dongoka; Pasch 1986: 240f) in fact displays three-way suppletion of $1 \mathrm{SG} 2 \mathrm{SG}$ elsewhere, which does not directly follow from the stated analysis.
} 
examples. On this view, we could interpret any pattern that unites $1^{\text {st }}$ and $2^{\text {nd }}$ person as the extension of an egocentric marking strategy to the $2^{\text {nd }}$ person. And this is in fact what seems to be happening in a number of the languages in the present sample.

In the most obvious case, there is a system in which $1^{\text {st }}$ and $2^{\text {nd }}$ person forms are distinguished from each other in principle, but the $1^{\text {st }}$ person form may optionally be extended to $2^{\text {nd }}$ person. For example, in Namia, the dictionary by Feldpausch, Feldpausch \& Yalweike (2011) gives distinct $2^{\text {nd }}$ person forms for a number of terms, but the grammar by Feldpausch \& Feldpausch (1992) consistently represents paradigms in which the $1^{\text {st }}$ person form is used for $2^{\text {nd }}$ person as well (20). The same variation is also found between the dictionary and grammar of Akoye. ${ }^{4}$

(20) Variation in Namia 'mother' between dictionary (Feldpausch, Feldpausch \& Yalweike 2011) and grammar (Feldpausch \& Feldpausch 1992:21)

\begin{tabular}{l}
\multicolumn{2}{c}{ dictionary $\quad$ grammar } \\
\begin{tabular}{|l|l|l|}
\hline 1 & mo & mo \\
\hline 2 & amao-ke & \\
\hline 3 & amao-le & amau-le \\
\hline
\end{tabular}
\end{tabular}

In other cases we have to rely on typological diagnostics. For example, in Usan (21), there is a group of non-suppletive kin terms that take transparently pronominal prefixes for all three persons, while suppletive items have a single $1^{\text {st }} / 2^{\text {nd }}$ person form. Crucially, this form is a bare stem, which we identified above $(\S 4.1)$ as a characteristic of $1^{\text {st }}$ person forms, while the $3^{\text {rd }}$ person form has the expected pronominal prefix. Unlike the Namia example above, this does not constitute extension of a $1^{\text {st }}$ person form, but it does arguably involve the use of

\footnotetext{
${ }^{4}$ In the case of Akoye, the grammatical description (Whitney \& Whitney 1991) has the full system, the later dictionary (Whitney 1995) systematically represents the system with $1^{\text {st }}$ and $2^{\text {nd }}$ person marking conflated.
} 
a typically $1^{\text {st }}$ person marking strategy. In this sense it resembles the Mauwake paradigm in (15), except that the intrusive suppletive form has taken over a greater portion of the paradigm. ${ }^{5}$

suppletive

'older brother'

\begin{tabular}{|l|l|l|l|l|}
\hline 1 & bain & imâ & tain & nani \\
\hline 2 & & & & \\
\hline 3 & ú-mom & u-móur & u-r & ú-nor \\
\hline
\end{tabular}

non-suppletive

'wife'

\begin{tabular}{|l|}
\hline yá-beni \\
\hline ná-beni \\
\hline ú-beni \\
\hline
\end{tabular}

In Kwomtari and Tauya we can bring evidence from lexical semantics to bear. Recall from $\S 3$ that where one of the suppletive roots is an improper kin term, it is the one used for $1^{\text {st }}$ person possessors. In these two languages we find exactly that for $1^{\text {st }}$ and $2^{\text {nd }}$ person forms (22)-(23), so that this combined form can be said to have properties otherwise associated with $1^{\text {st }}$ person possessors. (Note that the Tauya paradigm does not involve a pure opposition of person, as number is implicated too; see §5.)

Kwomtari (Spencer 2008:58)

'husband' 'wife' 'daughter'

\begin{tabular}{|l|l|l|l|}
\hline 1 & \multirow{2}{*}{ lufwa } & inali & auteli \\
\hline 2 & & & \\
\hline 3 & nuguli & nariemu & luali \\
\hline
\end{tabular}

lufwa 'man'

inali 'woman'

auteli 'girl'

\footnotetext{
5 The two languages are related, and the pronominal prefixes are obviously similar, but we can find no resemblance in the kin term roots.
} 
(23) Tauya (MacDonald 2013)

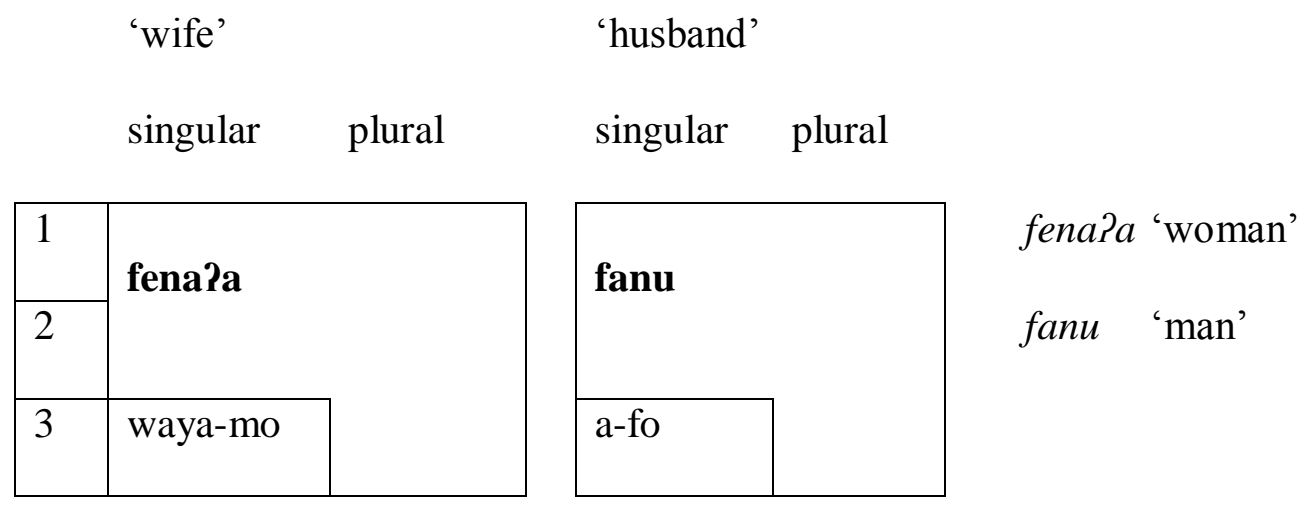

In Manem comparative evidence suggests that the form used with egocentric possessors is diachronically less stable: the two forms of 'mother', $1^{\text {st }} / 2^{\text {nd }}$ person bai, $3^{\text {rd }}$ person afa (Voorhoeve 1971:102) correspond to the single form afa-g in the related language Amanab (- $g$ is a frozen marker of inalienable possession; Minch 1992:125). Clearly it is the non-egocentric form which is stable across the two languages; following the arguments given above $(\S 3)$, diachronic mutability is a characteristic of $1^{\text {st }}$ person forms.

The examples surveyed above all involve the use of a single syncretic form for both $1^{\text {st }}$ and $2^{\text {nd }}$ person possessors, a form which often has the properties characteristic specifically of $1^{\text {st }}$ person possessors. This has allowed us to speculate that what is going on is that that the $1^{\text {st }}$ person form is being used for $2^{\text {nd }}$ person possessors as well. In the remaining examples, however, it is only the ROOT which is shared between $1^{\text {st }}$ and $2^{\text {nd }}$ person possessors, the forms otherwise being inflectionally distinct. These cases cannot be portrayed as the wholesale extension of a $1^{\text {st }}$ person form. In fact, in only one example does the shared root have any properties that we can identify as being explicitly those of a $1^{\text {st }}$ person possessor: in Ekagi 'father' $(24)$ the $1^{\text {st }} / 2^{\text {nd }}$ person -ajtaj is clearly related to the term of address ajta (Steltenpool 1969). Recall that, cross-linguistically, there is often a close association between terms of address and those used for $1^{\text {st }}$ person possessors (see the quote from Dahl \& KoptjevskajaTamm in $\S 1)$. 
(24) Ekagi (Drabbe 1952, repeated from (2) above)

'father'

\begin{tabular}{|c|l|}
\hline 1 SG & na-ajtaj \\
\hline $2 \mathrm{SG}$ & aka-ajtaj \\
\hline $3 \mathrm{SG}$ & na-kamee \\
\hline
\end{tabular}

What sets Ekagi apart from the examples surveyed earlier in this section is not just the lack of syncretism between $1^{\text {st }}$ and $2^{\text {nd }}$ person forms, but also the fact that the $1^{\text {st }}$ person form is not the bare stem. In fact, in all the examples where there is a suppletive $1^{\text {st }} / 2^{\text {nd }}$ person root (but no syncretism between the two person values), the $1^{\text {st }}$ person form is overtly affixed, namely in Salt-Yui (25), Kaluli (26) and Fas (27). While this is not a large number of examples, it is nonetheless striking, because there is a clear implication between the suppletive pattern and the morphological encoding of $1^{\text {st }}$ person: $1^{\text {st }} \sim$ non- $1^{\text {st }}$ suppletion implies a zero-marked $1^{\text {st }}$ person form. The non- $3^{\text {rd }} \sim 3^{\text {rd }}$ person patterns surveyed in this section allow for both zeromarked and overtly affixed $1^{\text {st }}$ person forms.

(25) Salt-Yui (Irwin 1974:28)

\begin{tabular}{l|l|l|} 
& suppletive & non-suppletive \\
& 'father' & 'wife' (root $e u$ ) \\
\hline 1 & na-abe & eu-na-bi \\
\hline 2 & n-ab-in & eu-ni-bi \\
\hline 3 & ira-ng & eu-ng-bi \\
\hline
\end{tabular}




\begin{tabular}{|l|l|l|} 
& $\begin{array}{l}\text { suppletive } \\
\text { 'daughter' }\end{array}$ & 'sister'suppletive \\
\hline 1 & n-a:la & n-ado \\
\hline 2 & g-a:la & g-ado \\
\hline 3 & ida & ado \\
\hline
\end{tabular}

'father'

\begin{tabular}{|l|l|}
\hline 1 & ay- $\varepsilon w$ \\
\hline 2 & ay \\
\hline 3 & bafo \\
\hline
\end{tabular}

Thus, in spite of the relative paucity of examples, $1^{\text {st }} / 2^{\text {nd }} \sim 3^{\text {rd }}$ suppletion presents a morphologically more diverse picture than $1^{\text {st }} \sim$ non- $1^{\text {st }}$. Some examples $((20)-(23))$ could be interpreted as resulting from the extension of a $1^{\text {st }}$ person form to $2^{\text {nd }}$ person possessors, so that one might lump them together with the examples described in $§ 4.1$ as egocentric forms, broadly construed. Other examples ((24)-(27)) appear to be a morphologically distinct phenomenon whose interpretation remains so far obscure.

\subsection{Second person $\sim$ non-second person}

With a $2^{\text {nd }} \sim$ non- $2^{\text {nd }}$ alternation, the $1^{\text {st }}$ person form shares a root with the $3^{\text {rd }}$ person. Can this be construed as an egocentric form, on analogy with $1^{\text {st }} / 2^{\text {nd }}$ person combinations in (20)-(23)? What little evidence there is suggests not. The one clear example in the sample comes from 
Vitu, where the terms for father and mother both have distinct roots in the 2SG, as well as an anomalous prefixal possessor marker in place of the expected suffix.

(28) Vitu (Bachet \& Van den Berg 2006:15, 53f)

\begin{tabular}{|l|l|l|l|}
\multicolumn{2}{c}{$\begin{array}{l}\text { suppletive } \\
\text { 'father' 'mother' }\end{array}$} & \multicolumn{1}{c|}{ 'spon-suppletive } \\
\multicolumn{1}{l}{ 's } & tama-gu & titina-gu & go-gu \\
\hline 2SG & ka-mama & ka-titi & go-o \\
\hline 3SG & tama-na & titina-na & go-na \\
\hline
\end{tabular}

The suppletive 2SG form has some properties - at least diachronically - otherwise characteristic of the $1^{\text {st }}$ person forms seen in $\$ 4.1$. First, it was based on a term of address: Bachet and Van den Berg (2006:54) observe that mama and titi are obsolete term of address, since replaced by the Tok Pisin loans papa and mama. (Titi remains in use for 'grandmother'.) Second, it appears to have originally been an uninflected form, based on a frozen version of the alienable possession construction, involving the general possessive classifier $k a$ with a 2 SG suffix, as in (28).

$\begin{array}{ll}\text { (29) } & \text { ruma } \\ \text { POSS-2SG } & \text { house } \\ \text { 'your house' } & \end{array}$

(Bachet \& Van den Berg 2006:53)

Thus the set of lexemes involved, and the substitution of a reduplicated term of address (mama) fits in with the parental prototype as described above. Only it is the $2 \mathrm{sG}$ form 
which is affected, not $1^{\text {st }}$. This suggests that the notion of egocentric reference is a parameter separable from the lexical semantic and morphological parameters.

The only other example comes from Kobon, where it is a minor phenomenon alongside a predominant pattern of $1^{\text {st }} \sim$ non- $1^{\text {st }}$ suppletion. Here it involves the terms for 'son' and 'daughter. As expected, one of the roots, which is used for $1^{\text {st }}$ person reference, is in fact an improper kin term ('boy', 'girl'), seen also in 'husband', where $1^{\text {st }}$ person $b \dot{t}$ is simply 'man' (see (11)). But in Davies's presentation of the data, the alternative root for 'son' and 'daughter' exists only for $2^{\text {nd }}$ person. As with other dedicated kin terms, it bears overt inflection for $2^{\text {nd }}$ person (all the 24 kin terms listed by Davies have the prefix $n a$-).

(30) Kobon (Davies 1981:234f)



\subsection{Three-way suppletion}

There are only a few examples of three-way suppletion in the sample, and they all occur in languages which also have one of the two-way patterns described above. Thus in Mauwake, the basic suppletive pattern involves a bare stem for the $1^{\text {st }}$ person, as in 'elder sibling' in (31). The three-way pattern in 'mother' involves, quite unusually, a bare stem in the $3^{\text {rd }}$ person as well, leaving only the $2^{\text {nd }}$ person form bearing an affix. 


\begin{tabular}{|c|c|c|c|}
\hline & non-suppletive & 2-way suppletion & 3-way suppletion \\
\hline & 'brother' & 'elder sibling' & 'mother' \\
\hline 1 & y-omokowa & paapa & aite \\
\hline 2 & n-omokowa & n-eepe & n-iena \\
\hline 3 & w-omokowa & w-eepe & onak \\
\hline
\end{tabular}

Telefol is similar, although here the basic pattern for kin terms is to have a bare stem in both $1^{\text {st }}$ and $3^{\text {rd }}$ person in any case. (The $t$ - in place of $k$ - in the $2^{\text {nd }}$ person form is phonologically regular before $/ \mathrm{i} /$, as in 'husband'.) Note that the $3^{\text {rd }}$ person root $f i k$ is cognate with Mian hek 'elder brother' which, like all kin terms in Mian, does not distinguish possessor person. ${ }^{6}$

Telefol (Healey 1962: 15f)

non-suppletive

'father's elder brother' 'husband'

\begin{tabular}{|l|l|l|}
\hline 1 & aaloob & imák \\
\hline 2 & k-aaloob & t-imák \\
\hline 3 & aaloob & imák \\
\hline
\end{tabular}

2-way suppletion 3-way suppletion

'cousin' 'elder brother'

\begin{tabular}{|l|l|}
\hline neék & baáb \\
\hline k-alák & t-iín \\
\hline alák & fik \\
\hline
\end{tabular}

In Kaluli it is the non- $3^{\text {rd }} \sim 3^{\text {rd }}$ person alternation which is primary. Suppletive items all have an initial $i$ - in the $3^{\text {rd }}$ person, though its status as an affix is unclear, since it is not found with non-suppletive items. In the three-way pattern, an intrusive uninflected $1^{\text {st }}$ person form is added for some lexemes, while the $2^{\text {nd }}$ and $3^{\text {rd }}$ person forms look morphologically like those found in 2-way suppletive patterns.

\footnotetext{
${ }^{6}$ On the sound correspondence /f / /h/, see Loughnane \& Fedden (2011).
} 


'sister'
\begin{tabular}{|l|l|l|l|}
\hline 1 & n-ado & n-a:la & do \\
\hline 2 & g-ado & g-a:la & g-ol \\
\hline 3 & ado & ida & iya \\
\hline
\end{tabular}

A particularly striking piece of evidence for the layered nature of 3-way suppletion comes from Ekagi, where Steltenpool's (1969) dictionary supplements the paradigm for 'father' with an additional $1^{\text {st }}$ person root.

(34) Ekagi 'father' (Drabbe 1952:16f, Steltenpool 1969)

\begin{tabular}{|c|l|}
\hline $1 \mathrm{SG}$ & na-ajtaj \\
\hline $2 \mathrm{SG}$ & aka-ajtaj \\
\hline $3 \mathrm{SG}$ & na-kamee \\
\hline
\end{tabular}

\begin{tabular}{|l|}
\hline wauwa \\
\hline aka-ajtaj \\
\hline na-kamee \\
\hline
\end{tabular}

\subsection{Person and number}

So far we have concentrated on person, avoiding explicit discussion of number. This is because in most of the examples number is not relevant, either because a single stem alternation pattern is maintained regardless of possessor number, or because possessor number is not distinguished at all. But there are also a number of languages where number also plays a role in shaping the paradigm, which means that there is more going on than just a person-based split. Below we review the paradigmatic properties of person and number marking in those languages that mark both number and person of the possessor. (Note that in some of the languages there may be divisions within non-singular number: dual, trial etc.; 
these are factored out here, since these additional number values always pattern together with the plural.)

In some of the languages the interaction is quite simple. Thus in the Angan languages (as indicated by the data from Kapau and Menya) possessor number is distinguished in the $2^{\text {nd }}$ person only. Suppletion here opposes the $1^{\text {st }}$ person root to the rest, so this number distinction plays no role. In the Oceanic languages of the sample (Siar-Lak, Kairiru, Vitu) and in the South Bougainville languages (Buin, Motuna), possessor person and number are consistently distinguished. Suppletion in these languages opposes a $1 \mathrm{SG}$ root to the rest, or in Vitu, 2SG to the rest.

(35) Person and number in the Angan languages

\begin{tabular}{|l|l|l|}
\multicolumn{1}{c}{ SG } & \multicolumn{2}{l}{ NON-SG } \\
\hline 1 & a & \\
\hline 2 & b & d \\
\hline 3 & c \\
\hline
\end{tabular}

(36) Person and number in the Oceanic and South Bougainville languages

\begin{tabular}{|l|l|l|}
\multicolumn{1}{c}{ SG } & \multicolumn{1}{c}{ NON-SG } \\
\hline 1 & a & d, e (INCL) \\
\hline 2 & b & f \\
\hline 3 & c & g \\
\hline
\end{tabular}

In the Mountain Ok languages, Haruai, Umbu-Ungu and in Tauya there is a more interesting interaction of person and number. Three patterns are found. 
The first pattern is that all the plural forms are the same as the 3SG form, and is said to occur in Telefol and Tifal (Healey 1962:20, Healey \& Steinkraus 1972:108). (In Telefol this exists alongside an alternative strategy in which there is no number distinction.) About Umbu-Ungu, Head (1976:22) writes that '[t]he third person form could be called the default form, in that it is usually used, along with the appropriate possessive pronoun, when referring to the kin of more than one person', which means at least some words display the pattern in (37a). (Unfortunately, since there are no examples in the text, it is not clear how restrictive the qualification USUALLY is.)

The second pattern is for the 2PL and 3PL forms to be the same as the $3 \mathrm{SG}$. This is found in Bimin (Weber 1997:20) and Haruai (Comrie \& Davies, in preparation). (Note that the conflation of 2PL and 3PL is also found in the verbal systems of these languages - as it also is in Telefol).

The third pattern occurs in Tauya, where the paradigm is organized into two forms, one for 3SG, one for the rest of the paradigm.

(37) Plural possessor marking patterns that conflate person; 'egocentric' cells are shaded

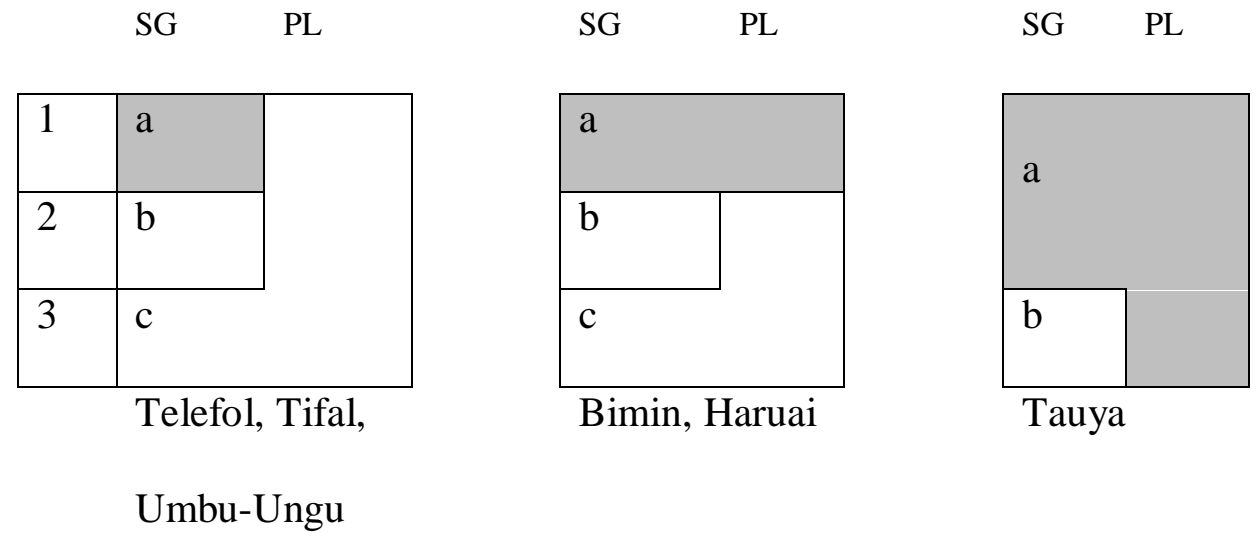

If we see possessor-based suppletion in terms of egocentric reference - arguably justified in these cases - the paradigm structures in (37) delimit what actually constitutes 
egocentric. But while the first two types still involve a distinction between $1^{\text {st }}$ person and the rest, the third involves a combination of person and number values. In the following section we will consider more closely the implications of this pattern.

\section{Discourse or paradigm?}

Are the patterns under investigation here determined lexically - e.g. as the pragmatically determined choice between two competing kin terms - or inflectionally, as morphologically stipulated suppletive paradigms? If the choice of forms is discourse-based, then we should expect (i) that the alternates be distributed according to a semantically coherent set of person values, (ii) that both alternates be available for possessors of all person values (although there may well be statistical preferences). Let us take up each of these two points in turn.

\subsection{Semantic coherence}

The less transparent the semantic motivation for a form, the more we may be inclined to turn to a morphological explanation. Most of the patterns surveyed here involve a simple opposition of three person values, where any configuration could in principle be given a semantic account. But where number starts to play a role, things may become less transparent. The most extreme example in the sample is Tauya (see (37)). In some respects kin terms in this language have the properties associated with an opposition between egocentric $\left(1^{\text {st }}\right.$ and $2^{\text {nd }}$ person, in this case $)$ and non-egocentric reference: the egocentric form is the bare stem, and for certain kin types, employs an improper kin term. But the actual distribution of forms is $3 \mathrm{SG}$ vs. non-3SG. This does not make a great deal of sense in semantic terms, as $\left\{1^{\text {st }} / 2^{\text {nd }}\right.$ singular+all plural $\}$ is a set of values hard to reconcile with the notion 'ego', however broadly construed. Rather, the division into $3 \mathrm{SG} \sim$ other appears to be a morphological fact of the paradigm, reflecting the affixation pattern of suppletive and non- 
suppletive items alike. This makes it an example of what Corbett (2007:18) calls MORPHOLOGICAL as opposed to MORPHOSYNTACTIC distribution of a suppletive root, in that it corresponds to a purely morphological pattern, and not to the value of a morphosyntactic feature. Note that in this case morphology and semantics are intimately bound, as the morphologically defined paradigm provides the template through which the semantic patterns are realized.

\subsection{Availability}

In a discourse-based competition between kin term doublets, possessor person may skew the statistics without conclusively assigning one alternate over the other. Consider the competition between English father $\sim$ dad and mother $\sim$ mom as revealed in the Corpus of Contemporary American English (COCA) ${ }^{7}$ in Table 2, showing instances where these terms appear preceded by possessive pronouns. ${ }^{8}$ What should be observed here is the 'nursery terms' mom and dad are more likely to be used with $1^{\text {st }}$ and $2^{\text {nd }}$ person possessive pronouns (as opposed to $3^{\text {rd }}$ person) than the corresponding neutral terms mother and father are. But we would have no justification in saying that $m o m$ and dad were specifically $1^{\text {st }} / 2^{\text {nd }}$ person forms, or in describing their distribution as being at all paradigmatic.

\footnotetext{
${ }^{7} \mathrm{http}: / /$ corpus2.byu.edu/coca/

${ }^{8}$ Similar results are obtained using equivalent terms in the British National Corpus.
} 
raw figures

\begin{tabular}{|l|l|l|}
\hline & father & dad \\
\hline my & 32875 & 8416 \\
\hline our & 982 & 192 \\
\hline your & 7844 & 2336 \\
\hline his & 31193 & 3435 \\
\hline her & 18061 & 1715 \\
\hline their & 3611 & 487 \\
\hline total & 94566 & 16581 \\
\hline
\end{tabular}

\begin{tabular}{|l|l|}
\hline mother & mom \\
\hline 36075 & 7808 \\
\hline 1037 & 172 \\
\hline 7991 & 2580 \\
\hline 22998 & 2213 \\
\hline 27530 & 2480 \\
\hline 3933 & 391 \\
\hline 99564 & 15644 \\
\hline
\end{tabular}

percentages of total by possessor person

\begin{tabular}{|l|l|l|}
\hline & father & dad \\
\hline $1^{\text {st }}$ & $36 \%$ & $52 \%$ \\
\hline $2^{\text {nd }}$ & $8 \%$ & $14 \%$ \\
\hline $3^{\text {rd }}$ & $56 \%$ & $33 \%$ \\
\hline
\end{tabular}

\begin{tabular}{|l|l|}
\hline mother & mom \\
\hline $37 \%$ & $51 \%$ \\
\hline $8 \%$ & $16 \%$ \\
\hline $55 \%$ & $32 \%$ \\
\hline
\end{tabular}

Table 2: Distribution by possessive pronoun of father vs. dad, mother vs. mom in COCA

Since all of the phenomena from the current sample reported here are described in paradigmatic terms, we assume that we should not view them in the same light. However, we do find instances of competition which are partly constrained by paradigmatic considerations, indicative perhaps of a mixture of discourse-based and morphological factors. For example in Haruai (38), Comrie \& Davies indicate that for at least some items, the (uninflected) $1^{\text {st }}$ person form can be used for any possessor person, though it is unclear what conditions this variation. This situation can be construed as the asymmetrical competition between two options, one of which is available to all possessors, the other only to a subset. 
(38) Haruai 'father' (Comrie \& Davies, in preparation)

option 1

\begin{tabular}{|l|l|}
\hline $1 \mathrm{SG}$ & acö \\
\hline $2 \mathrm{SG}$ & acö \\
\hline $3 \mathrm{SG}$ & acö \\
\hline
\end{tabular}

option 2

\begin{tabular}{|l|}
\hline nawö \\
\hline nwö \\
\hline
\end{tabular}

Such variation, involving the generalization of the form used for $1^{\text {st }}$ person possessors, is said to occur also in Tainae (Carlson 1991) and Kalam (Pawley 1966:87), and evidence for it can be found through a close reading of the descriptions of Namia, Tauya and Yale, where variation occurs in text examples. Where the generalized form is an improper kin term, or otherwise semantically distinct from the person-restricted kin term, one may be inclined to view this as lexical competition. Consider the paradigm of Kobon 'daughter', seen above in (30). Since pai is simply the generic word 'girl', it might better be represented as lexical competition between pai, available to all possessors, and the defective kin term bön, available only to $2^{\text {nd }}$ person possessors.

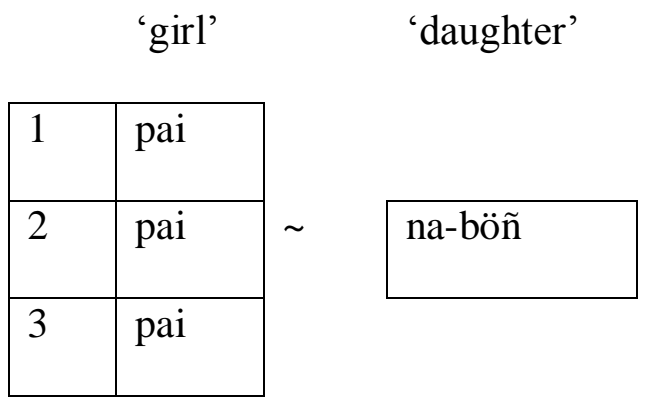

This is as if one could say 'your girl' or 'your daughter', but only 'my girl'. This corresponds to what (Corbett 2007:26, adapting a term from Juge 1999) calls DIRECTIONAL OVERLAPPING 
SUPPLETION. It is not suppletion in the canonical sense, but displays the crucial property of having a paradigmatically restricted root. $^{9}$

In all the cases alluded to so far, variation has in fact involved the choice between two coding strategies, either an uninflected form or an inflected form. In the sample there is only one exception to this, where there is just a single coding strategy, but variation between suppletive and non-suppletive root patterns ('alternating' suppletion in the sense of Corbett 2007:23). In Tainae the word 'wife' employs the improper kin term apaki 'woman' for $1^{\text {st }}$ person possessors and the dedicated kin term apepi for non- $1^{\text {st }}$ person (40), but there are examples in the text where $3^{\text {rd }}$ person possession is inflectionally marked with either root: $k i$ apepi or ki-apaki. It is not clear whether this should be analysed differently from the preceding examples, but it is noteworthy for its rarity, since there is nothing inherently unusual about it.

Tainae ‘woman/wife' (Carlson 1991:30, 42, 83) ${ }^{10}$

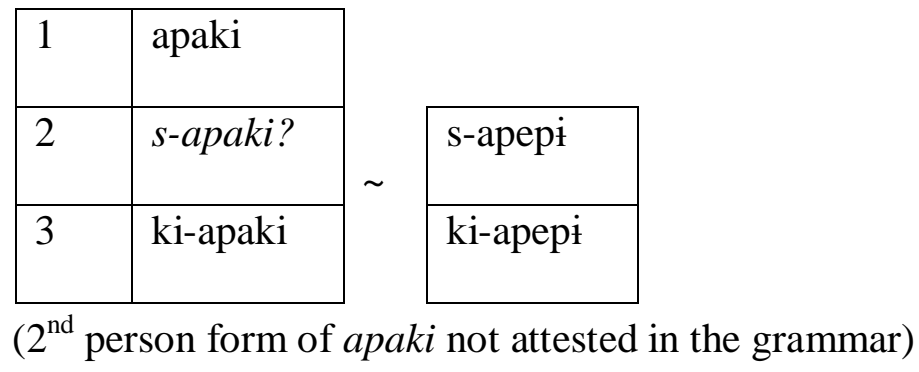

\footnotetext{
${ }^{9}$ Comrie \& Davies (in preparation) offer evidence from Haruai for a distinction between true suppletion and directional overlapping suppletion. Within the general pattern of $1^{\text {st }} \sim$ non- $1^{\text {st }}$ alternations, they analyse some items as suppletive, as in (38), and others as involving a defective item that lacks a $1^{\text {st }}$ person form, where another lexeme is substituted for the gap. In the former case, the default citation form is the $1^{\text {st }}$ person form, in the latter case it is the $3^{\text {rd }}$ person form. Unfortunately, we have insufficient information about the other languages in the present sample to know if anything similar happens in them.

${ }^{10}$ In the paradigm on p. 42 Carlson gives the $3^{\text {rd }}$ person form with the suffix $-p a$ in place of the feminine classifier -pi. The expected form kiapepi is given in the example sentence on p. 86, so we interpret this as a typo.
} 
In sum, many of the examples exhibit a state in between lexical competition and full paradigmaticity, where one root is available to all possessor persons, and another root available only to a restricted set, typically $2^{\text {nd }}$ and $3^{\text {rd }}$ person.

\section{Conclusion}

The kin terms surveyed here are remarkable in the way they deploy a phenomenon which is decidedly irregular, namely suppletion, with a remarkable degree of cross-linguistic consistency both morphologically and lexically. These patterns overlap to a great extent with the interplay of kin term doublets as discussed by Dahl and Kopjevskaja-Tamm (2001), suggesting that possessor person-based suppletion has its origins in the pragmatically determined choice of different lexical items. The overarching generalization is that the form used for ego - that is, $1^{\text {st }}$ person possessors - is singled out for special treatment, with the following properties:

- root is distinct from $2^{\text {nd }} / 3^{\text {rd }}$ person root

- form is uninflected

- shows tendency to replacement

- with terms for older relatives, use of 'nursery terms' such as mom, $\mathrm{dad}$

- with terms for spouses or children, use of improper kin terms (e.g. 'man', 'child')

But this being morphology, a simple functionally based explanation will never be the whole story.

First, all the other logically possible patterns of person-based suppletion are found as well. In some cases we might plausibly derive them from the dominant ego-based pattern (see 
the first half of $\S 4.2$ ). But there are also many cases where the motivation is opaque, at least given our current state of knowledge.

Second, the suppletive patterns may interact with more general morphological patterns in the language, as in Tauya, showing that whatever functional motivation an alternation may once have had, it can be adapted to the established morphological system. As a result, what we superficially label person-marking forms may in fact involve a disjunction of person values, possibly analysable as an elsewhere form.

Third, more general properties of morphological irregularity may be involved. In most of the languages under review here this possibility is obscured by the fact that kin terms form a distinct morphological system. But in one language (Tauya), body part terms may also show suppletive paradigms, along the same $3 \mathrm{SG} \sim$ non-3SG pattern as kin terms, e.g. mopu-fo $\sim$-momo 'body' (MacDonald 2013:55). ${ }^{11}$ Clearly, the discourse-driven arguments offered for kin terms cannot apply in the same way to body parts. Among other things, frequency may play a role here, independent of semantics.

The present pilot study embraces a diverse sample of 10-13 unrelated language families, so it is possible that the observations made here will scale up to the languages of the world as a whole. (Alternatively, it may turn out that New Guinea is a discrete linguistic area.) A central aim of this paper has been to establish a range of useful typological parameters as a prerequisite for a general cross-linguistic investigation. The available evidence shows that possessor person based suppletion - or at least what has been described as such - is widespread, though not exactly common. We are aware of the examples listed in Table 3:

\footnotetext{
${ }^{11}$ Unlike kin terms, other inalienably possessed nouns in Tauya have pronominal prefixes in the non-3sG forms.
} 


\section{Africa}

Afro-Asiatic* $\quad$ Yaaku (Hobley 1910:149f)

Bantu Proto-Bantu (Guthrie 1967, cited by Marck \& Bostoen 2011), and then variously across the family (e.g. Drossard 2004 cites Kikuyu, Dziebel 2007 cites Bemba and Nyamwezi, Vafaiean 2013 cites Ewondo, Van de Velde 2008:81 cites Eton)

Nilo-Saharan* Maa (Heine 1980), Ngiti (Kutsch-Lojenga 1994), Surmic languages: Majang (Unseth 1998) and Tirmaga (Bryant 1999: 52f)

Ubangi $\quad$ Mba languages (Pasch 1986, cited by Aikhenvald 2013)

\section{Australia}

Gunwinyguan Bininj Gun Wok (Evans 2003:44), Nunggubuyu (Heath, Rumsey \& Merlan 1982:13f)

\section{North America}

Caddo* $\quad$ Pawnee (Parks \& Pratt 2008:542)

Kiowa-Tanoan Kiowa (Watkins 1984:105)

Otomanguean Chichimec (de Angulo 1933:156; cited by Mel'čuk 2006:428)

Pomoan Kashaya (Buckley 1992:361, cited by Vafaeian 2013; Southern

Pomo (Walker 2010)

Siouan

Assiniboine (Cumberland 2005:141f), Lakhota (Buechel 1939:103,

cited by Croft 1990)

\section{South America}


Macro-Je Karaja (Ribeiro 2012:38)

Tupian Sataré-Mawé (Koch-Grünberg 1932:39, cited by Dziebel 2007)

* We were made aware of these by Dziebel (2007), but have used sources other than the ones he has cited for Yaaku, Maa, Tirmaga and Pawnee

Table 3: Languages outside of New Guinea with possessor person-based suppletion in kin terms

We should also mention Japanese here, where kin terms have plain and honorific forms, the opposition being suppletive for some items. Their use at least approaches a $1^{\text {st }} \sim$ non- $1^{\text {st }}$ distinction (Kaiser et al. 2001, Ortmann 2006), though otherwise person is not generally considered a morphosyntactic feature of Japanese.

In general terms the behaviour of the languages listed in Table 3 resembles what we have seen in New Guinea: a predominance of $1^{\text {st }} \sim$ non- $1^{\text {st }}$ person alternations, but the existence of other alternations as well. The range is illustrated in (41): $1^{\text {st }} \sim$ non- $1^{\text {st }}$ (Tirmaga), non- $3^{\text {rd }} \sim 3^{\text {rd }}$ (Camus), non- $2^{\text {nd }} \sim 2^{\text {nd }}$ (Kiowa) and 3-way (Majang). The same themes reoccur here too, e.g. the egocentric use of CVCV nursery terms in Tirmaga and Camus, or the fact that the $2^{\text {nd }}$ person root in Kiowa is transparently related to a term of address (by reduplication: $t \hat{s}:)$, just as in Vitu (see (28) above). 
(41) Different suppletive patterns for 'father' in four languages (Bryant 1999:52f, Heine 1980:110, Watkins 1984:105 \& Harrington 1928:160, Unseth 1998:154)

Tirmaga Camus $\quad$ Kiowa
\begin{tabular}{|l|l|l|l|l|}
\hline 1SG & babáá & papá & nó:-tól & bààbéy \\
\hline 2SG & cógó-nú & papá & tò:tó & báá6á \\
\hline 3SG & cógó-né & ményé & tól & ćpén \\
\hline
\end{tabular}

But equally, these tendencies interact with idiosyncratic (or at any rate, languageparticular) morphological patterns. Consider the Ngiti word for 'mother' in (42), which has the roots $i y a$ and $t s a$. It is as good as impossible to motivate the distribution of these roots semantically, as their sets of values do not constitute any coherent natural class. For example, ts $a$ combines $3^{\text {rd }}$ person and $1^{\text {st }}$ person inclusive, while tya combines $1^{\text {st }}$ person singular and $3^{\text {rd }}$ person logophoric possessors. But the distribution is easily accounted for in morphological terms: $t s a$ is used when there is a prefix, $\dot{t} y a$ when there is no prefix.

(42) Ngiti (Kutsch Lojenga 1994:143, 204)

suppletive 'mother'

singular plural

\begin{tabular}{|l|l|l|}
\hline 1 INCL & ------ & àle-tsá-nà \\
\hline 1 & f́yà-du & íyà-kà \\
\hline 2 & íyà-nu & '́yà-ku \\
\hline 3 & kà-tsá-nà & abádhí-tsá-nà \\
\hline LOG & f́yà-nà & ́́yà-yà \\
\hline
\end{tabular}

Note: unmarked vowels have low-mid tone non-suppletive 'sister'

singular plural

\begin{tabular}{|c|c|}
\hline ------- & al-avhغ̀-nà \\
\hline avhè-du & avhè-kà \\
\hline avhè-nu & avhغ̀-ku \\
\hline k-avhè-nà & abádhi-avhè-nà \\
\hline avhè-nà & avhè-yà \\
\hline
\end{tabular}


From the perspective of morphological typology, the most compelling issue that further cross-linguistic study can address is how the functional and discourse-based oppositions are integrated into the morphological system. While the genesis of suppletion through the merger of distinct lexemes into a single paradigms has been explored for individual languages or language families (e.g. Chumakina, Hippisley \& Corbett 2004 on Russian, Juge 1999 on Spanish, Strunk 1977 on Indo-European), the phenomena discussed in the present study present an opportunity to trace very similar processes in parallel across a wide variety of languages.

Correspondence address

Surrey Morphology Group [I1]

University of Surrey

Guildford, Surrey GU2 7XH

United Kingdom

m.baerman@surrey.ac.uk

Acknowledgments

This research was funded by the European Research Council (ERC-2008-AdG-230268 MORPHOLOGY), whose support is gratefully acknowledged. Thanks to Sebastian Fedden and to three anonymous reviewers for their helpful comments, to Dunstan Brown, Marina Chumakina, Scott Collier, Grev Corbett, and Serge Sagna for comments on earlier drafts, and to Penny Everson for assistance in preparation of the final manuscript.

Abbreviations 
INCL-inclusive, PL-plural, POSS-possession, SG-singular,

\section{References}

Aikhenvald, Alexandra Y. 2013. Possession and ownership: a cross-linguistic perspective. In Possession and ownership: a cross-linguistic typology, ed. by Alexandra Y. Aikhenvald and R.M.W. Dixon, pp. 1-64. Oxford: OUP.

Bachet, Peter and René van den Berg. 2006. Vitu grammar sketch. Ukarumpa, EHP: SIL. Online: http://www.sil.org/pacific/png/abstract.asp?id=47977.

Bally, Charles. 1995 [1926]. The expression of concepts of the personal domain and indivisibility in the Indo-European languages. In Hilary Chappell \& William McGregor (eds) The grammar of inalienability, pp. 31-64. Berlin: Mouton de Gruyter. Originally published 1926 as L'expression des idées de sphère personelle et de solidarité dans les langues indoeuropéennes, in Franz Fankhauser (ed.) Festschrift Louis Gauchat zu seinem 60. Geburtstage, 12. Januar 1926 von Freunden und Schülern aus der Schweiz gewidmet. Aarau: Sauerländer.

Baron, Wietze. 1986. Malay influence on West Sepik kinship terminology. Paper read at the Linguistic Society of Papua New Guinea. Online: http://www.kwomtari.net/malayinf.pdf. Berghäll, Liisa. 2010. Mauwake reference grammar. PhD thesis, University of Helsinki. Online: https://oa.doria.fi/handle/10024/63602.

Boush, Alfred. 1975. Tifal grammar essentials. Ms., SIL. Online: http://www.sil.org/pacific/png/abstract.asp?id=49130.

Brown, Dunstan, Marina Chumakina, Greville G. Corbett \& Andrew Hippisley. 2004. The Surrey suppletion database. Online: http://www.smg.surrey.ac.uk/.

Bryant, Michael Grayson. 1999. Aspects of Tirmaga grammar. PhD thesis, University of Texas at Arlington. 
Buckley, Eugene Lorenz. 1992. Theoretical aspects of Kashaya morphology and phonology. $\mathrm{PhD}$ thesis, University of California at Berkeley.

Buechel, Eugene. 1939. A grammar of Lakota. Rosebud, South Dakota: Rosebud Educational Society.

Campbell, Carl \& Jody Campbell. 1987. Yade grammar essentials. Ms, SIL. Online: http://www.sil.org/pacific/png/abstract.asp?id=928474549089.

Carlson, Terry. 1991. Tainae grammar essentials. Ms., SIL. Online: http://www.sil.org/pacific/png/abstract.asp?id=48961.

Chumakina, Marina, Andrew Hippisley and Greville G. Corbett. 2004. Istoričeskie izmenenija v russkoj leksike: slučaj čeredujuščegosja suppletivizma [Historical changes in the Russian lexicon: a case of alternating suppletion] Russian Linguistics 28. 281-315.

Comrie, Bernard \& John Davies, in preparation. A grammar of Haruai.

Corbett, Greville G. 2007. Canonical typology, suppletion and possible words. Language 83.1. $8-42$.

Croft, William. 1990. Typology and Universals. Cambridge: CUP.

Cumberland, Linda A. 2005. A grammar of Assiniboine: a Siouan language of the Northern Plains. PhD thesis, Indiana University.

Dahl, Östen and Koptjevskaja-Tamm, Maria. 2001. Kinship in grammar. In Dimensions of possession, ed. by Irène Baron, Michael Herslund and Finn Sørensen , pp. 201-225. Amsterdam/Philadelphia: John Benjamins.

Davies, John. 1981. Kobon. Amsterdam: North Holland Publishing Company. de Angulo, Jaime. 1933. The Chichimeco language (Central Mexico). International Journal of American Linguistics 7.152-193.

Dobrin, Lise M. 1997. Lexical splitting in the kinship vocabulary of the Buki Arapesh languages. Language and Linguistics in Melanesia 18. 99-118. 
Drabbe, Peter. 1952. Spraakkunst van het Ekagi. 'S-Gravenhage: Martinus Nijhoff.

Drossard, Werner. 2004. Einige ergänzende Bemerkungen zur Dimension der POSSESSSION. In Dimensionen und Kontinua. Beiträge zu Hansjakob Seilers Universalienforschung, ed. by Waldfried Premper, pp. 97-109. Bochum: Brockmeyer.

Dziebel, German V. 2007. The genius of kinship. Youngstown, NY: Cambria Press.

Evans, Nicholas. 2003. Bininj Gun-wok: A pan-dialectal Grammar of Mayali, Kunwinjku and Kune (Vol. 1) (Pacific Linguistics 541). Canberra: Australian National University. Fedden, Sebastian. 2011. A grammar of Mian. Mouton Grammar Library 55. Berlin: De Gruyter Mouton.

Feldman, Harry. 1986. A grammar of Awtuw. (Pacific Linguistics B-944). Canberra: Australian National University.

Feldpausch, Becky and Thomas Feldpausch. 1992. Namia grammar essentials. In Namia and Amanab grammar essentials, ed. by John R. Roberts, pp. 1-97. Ukarumpa: SIL. Online: http://www.sil.org/pacific/png/abstract.asp?id=34683.

Feldpausch, Thomas, Becky Feldpausch and Joas Yalweike. 2011. Namia dictionary. Ms., SIL. Online: http://www.sil.org/acpub/repository/Namia_dict_2011.pdf.

Grosh, Andy, \& Sylvia Carlsons Grosh. 2004. Grammar essentials for the Kaluli language. Ms., SIL. Online: http://www.sil.org/pacific/png/abstract.asp?id=51986.

Guthrie, Malcolm. 1967. Comparative Bantu: an introduction to the comparative linguistics and prehistory of the Bantu languages (Vol. 1). Farnborough: Gregg Press.

Harrington, John P. 1928. Vocabulary of the Kiowa language. (Bureau of American Ethnology Bulletin No. 84). Washington: U.S. Government Printing Office.

Head, June. Available: 1976. A grammar of Umbu-Ungu. Ms., SIL. Online: http://www.sil.org/pacific/png/abstract.asp?id=92847454277. 
Healey, Alan. 1962. Linguistic aspects of Telefomin kinship terminology. Anthropological Linguistics 4. 14-28.

Healey, Phyllis M. \& Walter Steinkraus. 1972. A preliminary vocabulary of Tifal with grammar notes. Dallas: SIL.

Heath, Jeffrey. 1982. Introduction. In Heath, Rumsey \& Merlan, pp. 1-18.

Heath, Jeffrey. 2004. Person. In Morphologie: Ein internationales Handbuch zur Flexion und Wortbildung / Morphology: An International Handbook on Inflection and WordFormation, ed. by Geert Booij, Christian Lehmann, Joachim Mugdan and Stavros Skopeteas, pp. 998-1015. Berlin: de Gruyter.

Heath, Jeffrey, Alan Rumsey \& Francesca Merlan (eds). 1982. The Languages of kinship in Aboriginal Australia. Sydney: University of Sydney.

Heine, Bernd. 1980. Camus, a Maa dialect. In Heine, Bernd (ed.), The Non-Bantu languages of Kenya, pp. 99-140. Berlin: Dietrich Reimer.

Hobley, Charles William. 1910. Ethnology of A-Kamba and other East African tribes. Cambridge: The University Press.

Irwin, Barry. 1974. Salt-Yui grammar. (Pacific Linguistics B-35). Canberra: Research School of Pacific and Asian Studies, Australian National University

Juge, Matthew L. 1999. On the rise of suppletion in verbal paradigms. Berkeley Linguistics Society 25. 183-94.

Kaiser, Stefan, Yasuko Ichikawa, Noriko Kobayashi, \& Hilofumi Yamamoto. 2001. Japanese: A comprehensive grammar. London: Routledge.

Koch, Harold. 1995. The creation of morphological zeros. In Geert Booij \& Jaap van Marle (eds) Yearbook of Morphology 1994, pp. 31-72 Dordrecht: Kluwer.

Koch-Grünberg, Theodor. 1932. Wörterlisten «Tupý», Maué und Purúborá. Journal de la Société des Américanistes XXIV. 31-50. 
Kutsch Lojenga, Constance. 1994. Ngiti: a Central-Sudanic language of Zaire. Köln: Rüdiger Köppe.

Lawrence, Marshall. 2006. Oksapmin dictionary. Ms, SIL. Online: http://www.sil.org/pacific/png/abstract.asp?id=48954.

Loughnane, Robyn and Sebastian Fedden. 2011. Is Oksapmin Ok? - A study of the genetic relationship between Oksapmin and the Ok languages. Australian Journal of Linguistics 31. 1-42.

Loughnane, Robyn. 2009. A grammar of Oksapmin. PhD Thesis, University of Melbourne. MacDonald, Lorna. 1990. A grammar of Tauya. Berlin: Mouton de Gruyter.

MacDonald, Lorna. 2013. A dictionary of Tauya (Pacific Linguistics 638). Berlin: Mouton de Gruyter.

Marck, Jeff , \& Koen Bostoen. 2011. Proto Oceanic society (Austronesian) and Proto East Bantu society (Niger-Congo), residence, descent and kin terms ca. 1000 BC. In Kinship, language, and prehistory: Per Hage and the renaissance in kinship studies, ed. by Dougles Jones \& Bojka Milicic, pp. 83-94. Salt Lake City : University of Utah Press. Mel'čuk, Igor A. 1994. Suppletion: toward a logical analysis of the concept. Studies in Language 18. 339-410.

Mel'čuk, Igor A. 2006. Aspects of the theory of morphology, ed. by David Beck. Berlin: Mouton de Gruyter.

Michael, Lev. 2013. Possession in Nanti. In Possession and ownership: a cross-linguistic typology, ed. by Alexandra Y. Aikhenvald and R.M.W. Dixon, pp. 149-166. Oxford: OUP. Minch, Andrew. 1992. Amanab grammar essentials. In Namia and Amanab grammar essentials, ed. by John R. Roberts, pp. 99-173. Ukarumpa: Summer Institute of Linguistics. Online: http://www.sil.org/pacific/png/abstract.asp?id=34684. 
Oates, William J. \& Lynette F. Oates. 1968. Kapau pedagogical grammar. Pacific Linguistics C-10. Canberra: The Australian National University.

Onishi, Masayuki. 1994. A grammar of Motuna (Bougainville, Papua New Guinea). PhD thesis, Australian National University.

Ortmann, Albert. 2006. Irregular valency alternations in possessive contexts. Talk given at the Societas Linguistica Europaea 39, Bremen, September 1.

Parks, Douglas R. and Pratt, Lula Nora. 2008. A Dictionary of Skiri Pawnee. Lincoln, NE: University of Nebraska Press.

Pasch, Helma. 1986. Die Mba-Sprachen. Köln: Rüdiger Köppe.

Pawley, Andrew. 1966. The structure of Karam: a grammar of a New Guinea Highlands language. $\mathrm{PhD}$ thesis, University of Auckland. Online: https://researchspace.auckland.ac.nz/handle/2292/835.

Reesink, Ger P. 1987. Structures and their functions in Usan: a Papuan language of Papua New Guinea. Amsterdam: John Benjamins.

Ribeiro, Eduardo Rivail. 2012. A grammar of Karajá. PhD thesis, University of Chicago.

Rowe, Karen. 2005. Siar-Lak grammar essentials. Ukarumpa: SIL. Online: http://www.sil.org/pacific/png/abstract.asp?id=46881.

Sanders, Arden G. \& Joy Sanders. 1994. Kamasau (Wand Tuan) grammar: morpheme to sentence. Ms., SIL. Online: http://www.sil.org/pacific/png/abstract.asp?id=47683.

Speece, Richard F. 2006. Angave dictionary. Ms., SIL. Online: http://www.sil.org/pacific/png/abstract.asp?id=48458.

Spencer, Katharine. 2008. Kwomtari grammar essentials. In Kwomtari phonology and grammar essentials, ed. by Murray Honsberger, Carol Honsberger\& Ian Tupper, pp. 53183. Ukarumpa: SIL-PNG Academic Publications. Online:

http://www.sil.org/pacific/png/abstract.asp?id=50948. 
Steltenpool, J. 1969. Ekagi-Dutch-English-Indonesian Dictionary. Verhandelingen van het KITLV, 56. 56. 269. The Hague: Martinus Nijhoff.

Stephaniw, Roman. 1987. A comparison of Imbongu grammar with the Kaugel grammar essentials. Ms., SIL. Online: http://www.sil.org/pacific/png/abstract.asp?id=928474543852.

Strunk, Klaus. 1977. Überlegungen zu Defektivität und Suppletion im Griechischen und Indogermanischen. Glotta 55. 2-34.

Unseth, Peter. 1998. Notes on clan, kinship and marriage patterns among the Majang. In Surmic languages and cultures, ed. by Gerrit Dimmendaal, and Marco Last, pp. 145-178. Köln: Rüdiger Köppe Verlag.

Vafaeian, Ghazaleh. 2013. Typology of nominal and adjectival suppletion. Sprachtypologie und Universalienforschung 66.2. 112-140

Van de Velde, Mark. 2008. A grammar of Eton. Berlin: Mouton de Gruyter.

Voorhoeve, C. L. 1971. Miscellaneous notes on languages in West Irian, New Guinea (Papers in New Guinea Linguistics No. 14). Canberra. Pacific Linguistics.

Walker, Neil Alexander. 2010. Teaching and Documenting an Endangered Language: Meeting the needs of scholars and heritage learners with a Southern Pomo dictionary. Talk at the $5^{\text {th }}$ UC Language Consortium Conference on Theoretical and Pedagogical Perspectives, UC San Diego.

Watkins, Laurel J. 1984. A grammar of Kiowa. Lincoln, NE: University of Nebraska Press. Weber, Thomas. 1997. Bimin grammar essentials. Ms. SIL. Online: http://www.sil.org/pacific/png/abstract.asp?id=928474543843.

Whitehead, Carl R. 2004. A reference grammar of Menya, an Angan language of Papua New Guinea. $\mathrm{PhD}$ thesis, University of Manitoba. Online: http://www.sil.org/pacific/png/abstract.asp?id=44419. 
Whitney, Henry \& Virginia Whitney, Virginia. 1991. Akoye grammar essentials. Ms., SIL.

Online: http://www.sil.org/pacific/png/abstract.asp?id=52560.

Whitney, Henry. 1995. Akoye triglot dictionary. Ms., SIL. Online:

http://www.sil.org/pacific/png/abstract.asp?id=52509.

\section{Additional resources used but not cited in text}

Bunn, Gordon. 1974. Golin grammar. Ukarumpa: SIL. Online:

http://www.sil.org/pacific/png/abstract.asp?id=10339.

Evans, Nicholas. Forthcoming. Inflection in Nen. In The Oxford Handbook of Inflection, ed. by Matthew Baerman. Oxford: OUP.

Farr, Cynthia J. and James B. Farr. 2008. Korafe-Yegha da dikiseneri (The Korafe-Yegha dictionary). SIL PNG. Online: http://www.sil.org/pacific/png/abstract.asp?id=50567.

Foreman, Velma M.. 1974. Grammar of Yessan-Mayo. Santa Ana, CA: SIL. Online: http://www.sil.org/acpub/repository/10677.pdf.

Laycock, Donald C.. 2003. A dictionary of Buin, a language of Bougainville (Pacific Linguistics, 537). 537. Canberra: Research School of Pacific and Asian Studies, Australian National University

Malcolm Ross. 2002. Kaulong. In The Oceanic languages, ed. by John Lynch, Malcolm Ross and Terry Crowley, pp. 387-409. Richmond: Curzon.

Pawley, Andrew \& Ralph Bulmer. 2011. A dictionary of Kalam with ethnographic notes (Pacific Linguistics 630). 630. 810. Canberra: Research School of Pacific and Asian Studies, Australian National University.

Stringer, Mary \& Joyce Hotz. 1973. The Occurrence and co-occurrence of Waffa noun suffixes. In The languages of the Eastern family of the East New Guinea Highlands stock, ed. by Howard P. In Mckaughan, pp. 547-556. Seattle: University of Washington. 
van den Heuvel, Wilco. 2006. Biak: description of an Austronesian language of Papua. $\mathrm{PhD}$ Thesis, University of Amsterdam.

Weimer, Harry \& Natalia Weimer. 1974. Yareba language. (Dictionaries of Papua New Guinea 2). Ukarumpa: SIL.

Weimer, Harry \& Natalia Weimer. 1975. A short sketch of Yareba grammar. In Studies in languages of central and south-east Papua (Pacific Linguistics C 29), ed. by T. E. Dutton, pp. 667-729. Canberra: Australian National University.

Whitacre, Steve. 1986-12. Arop/Sissano grammar essentials. Ms, SIL. Online: http://www01.sil.org/pacific/png/pubs/928474556320/Arop-Sissano_Grammar_Essentials.pdf.

Wivell, Richard/ 1981. Kairiru grammar. M.A. thesis, University of Auckland. Online: http://www.sil.org/pacific/png/abstract.asp?id=928474543558. 